\title{
Smart Structure Systems
}

\author{
平 石 久 廣*
}

\section{1. 高知能構造の概要}

\section{日米共同研究}

高知能構造とは構造物自体がセンサー (神経), プロ セッサー（頭脳）およびアクチュエーター（筋肉）を備 えたもの，すなわち疑似生体化した構造物といえ，以下 の機能を有する。

1.ひずみや損傷の発生, 劣化等を自己診断し,

2. 状態に応じて形状を自ら変化させ,

3. 振動・騒音等を自己制御し,

4. 必要に応じて損傷等の進展を自己抑制・修復す る。

このような機能を有する高知能構造は, 構造物の性能 の向上，長寿命化において無限の可能性を有していると いえる。特に米国では軍民転換プログラムの一貫として 力が注がれ, 航空・宇宙, 建設・土木分野等で研究開発 が盛んである。90 年代に入ってからはこの分野の技術 情報が米国に集中する観すらある。建築・土木に関して は 1993 年に NSF によるワークショップが開かれ，高 知能材料システムと高知能構造の開発の必要性に関する 報告が提出され，その社会的重要性が強く指摘されてい る。

\section{2. 高知能材料}

高知能構造を構成する高知能材料は「環境変化に知的 に応答し，機能を発現する能力を有する新物質・材料」 として 1989 年に日本で提案された新しい概念であり, 材料科学の発展の流れ (図-1 参照) から以下のように 位置づけられている。すなわち今までの材料に要求され てきた主な性能は，その材料の機械的強度であったとい え，これらの材料としては，順を追って，天然材料の形 状のみを変えたもの（石器等）から, 天然材料から有用 成分のみを抽出して成形したもの (青銅器, 鉄器等), プラスチック等の合成材料などがある。次世代に登場し たのが，機械的強度をより効率よく発揮させうる複合材 料（合金等）である。これに対し現在の材料に主として 要求される性能は, 機能的性質であり, 科学技術の急速 な発展をもたらした，シリコン $(\mathrm{Si})$ の集積回路はその

* ひらいし・ひさひろ/建設省建築研究所 第三研究部長 (正会員)
最たる例である。いわば現在に求められている材料は

「機能材料」といえる。

高知能材料とはこの材料発展の流れの先にあり, 材料 自身の中に知的機能の一部を求め，材料自身が劣化を診 断し，抑制や修復あるいは寿命予測を行うことが考えら れている。そしてより生体に近い機能を有し，ある意味 では生命をも凌駕する超機能材料と定義づけられてい る。

しかしながらここの知的機能を実現するための手段に おいて日本と欧米では差が見られる（図一2参照）。日本 における知的材料/構造に関する研究は材料レベルの基 礎的研究が主流であり欧米では応用ターゲットを明確に した材料/構造システムレベルの研究開発が主流であ る。



図-1 材料科学の発展の流れ

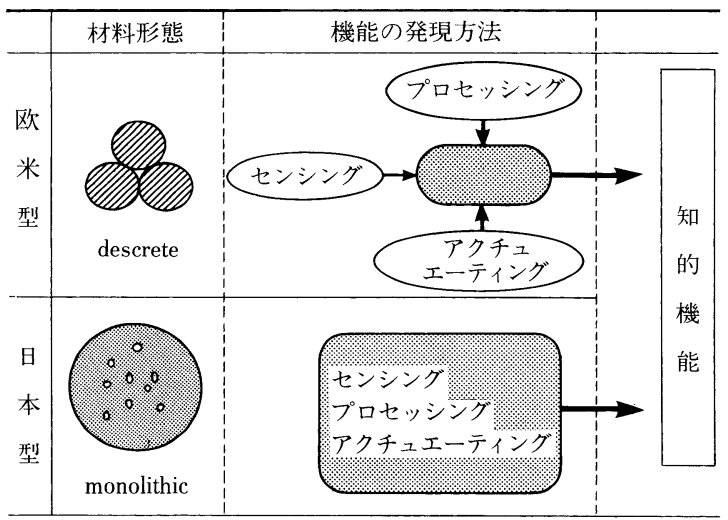

図-2＼cjkstart材料の形態と機能の発現方法 


\section{3. 実現が期待される構造}

表-1 には代表的な高知能システムの要素技術を示 す。また高知能構造システムの概念図を図一 3 に示す。

文献 1) には建築および土木構造分野において期待さ れるニーズとして以下の項目があげられている。

(1) ヘルスモニタリング機能

1）高速道路, 鉄道, 上下水道, 電力・ガス等インフ ラ構造物の破壊予知による安全性の向上

2）地中・海中構造物（例 トンネル, 海中トンネ ル，〈いなど）で直接目視による安全性の確認ので きない構造物の安全性の向上

3）原子炉など人間が接近できない構造物の破壊予知 と自己修復

4) 落石, 雪崩, 土砂崩落などの予知

(2) 経済的効果

1）長寿命によるライフサイクルコストの低減

2) モニタリングシステムの完備による設計安全率の 低減

3）地球にやさしい，環境に負担を与えない（リサイ クル可能な材料)

(3) 多機能材料

1) 電磁波吸収性, 熱線吸収, 吸音効果など多機能を 附加する

2) 居住空間の温度, 湿度, 空気清浄, 香りなど, 環 境を調整する機能を附加する

（4）居住性の向上

1）風などによる建造物の摇れの制御
表-1 要素技術

\begin{tabular}{|c|c|}
\hline 材 & $\begin{array}{l}\text { ・目材 } \\
\text { ・埋め込み技術 }\end{array}$ \\
\hline セ ン サ - & $\begin{array}{l}\text { •光ファイバーセンサー } \\
\text { •形状記憶合金センサー } \\
\text { • 圧電材料センサー } \\
\text { • 電歪センサー } \\
\text { • AE センサー }\end{array}$ \\
\hline アクチュエーター & $\begin{array}{l}\text { - 圧電材料 } \\
\text { - 形状記憶合金 } \\
\text { - 電気粘性流体 }\end{array}$ \\
\hline プロセッサー & $\begin{array}{l}\text { ・ 小型プロセッサー } \\
\text { ・高速プロセッサー }\end{array}$ \\
\hline 自己修 復 & - 自己修復型複合材料 \\
\hline
\end{tabular}

2）高架鉄道などの軀体振動の制御

3) アクティブノイズ制御（分布定数系スマートアク チュエイター)

4.おわりに

建設省建築研究所では建築構造の分野において米国科 学財団 (NSF) と日米共同耐震研究を実施しており, 現 在ハイブリッド構造に関する研究を行っている。さらに 平成 10 年度よりこの高知能構造に関して 5 力年の日米 共同研究を企画している。民・学・官, 特に民間からの 積極的な共同研究への参加・技術協力を期待している。

\section{引用文献}

1) 知的構造システムの先導研究 : 新エネルギー・産業技術総合開発 機構, 平成 8 年度 先導研究報告書, NEDO-PR-9611, 平成 9 年 3 月

1 ) 電気粘性流体 $(\mathrm{ERF}) \cdot$ 磁性粘性流体 $(\mathrm{MRF})$

電界強度または磁場強度を変化させることによって 見かけの粘性が変化する流体を電気粘性流体 (ERF： Electric Rheological Fluid) または磁性粘性流体 (MRF Magnetic Rheological Fluid) といい, ダンパーとして 部材に組み込める可能性がある。



（a）電压の変化による粘性の増大

(b) 建築骨組へのダンパーと しての応用

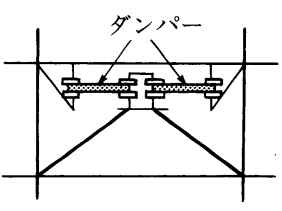

架構内の取り付け状況

（d）ワイア状の形状記憶合金を利用したダンパーとその性状

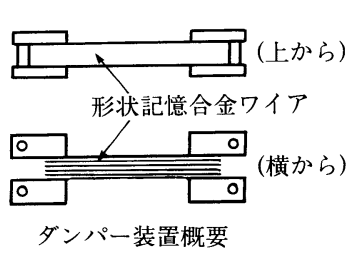

2 ) 形状記憶合金

形状記憶合金は“形状記憶性”と“超 弾性”の 2 つの性質を持っており，形 状記憶性を利用したセンサーや, 超弾 性を利用したエネルギー吸収性として の利用が可能である。特に, 応力・U ずみ履歴によるエネルギー吸収性を利 用したダンパーとして部材に組み込め る可能性がある。

3 ) 自己修復型複合材料

欠陥を自己修復あるいは抑制する材料としては 亀裂が生じるとコンクリート中に埋め込まれた カプセルが壊れて中の補修剤が溶出するものや, 鋼材の亀裂の進展を阻止する超高アレスト鋼板 など，さまざまなタイプがある。

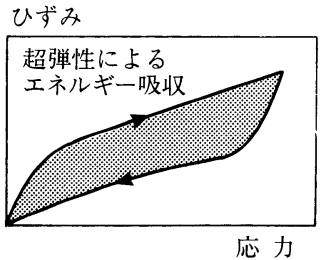

（c）形状記憶合金の応用 • ひずみ関係
(3)



亀裂の発生によるカプセルの破壊、補修材による龟裂の修復

（e）カプセル内包コンクリートの機能発現の概念図

図-3 高知能材料とその応用例 